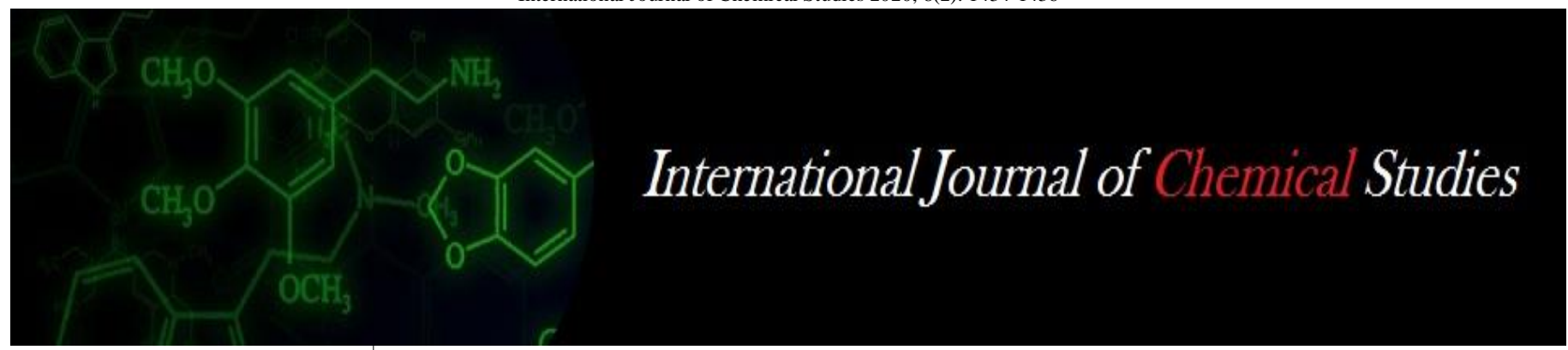

P-ISSN: 2349-8528

E-ISSN: 2321-4902

www.chemijournal.com

IJCS 2020; 8(2): 1434-1436

(C) 2020 IJCS

Received: 16-01-2020

Accepted: 18-02-2020

Sukanya Pachani

M.Sc., in Soil Science, Assam

Agricultural University, Jorhat,

Assam, India

Namrata Kashyap

Ph.D., Research Scholar in Soil

Science and Agricultural

Chemistry, CSAU\&T, Kanpur,

Uttar Pradesh, India
Corresponding Author: Sukanya Pachani

M.Sc., in Soil Science, Assam Agricultural University, Jorhat, Assam, India

\section{Soil health and its quality: A Review}

\author{
Sukanya Pachani and Namrata Kashyap
}

DOI: https://doi.org/10.22271/chemi.2020.v8.i2v.8966

\section{Abstract}

Soil health and soil quality are important for conserving the ecological biodiversity and maintaining environment equality within land use boundaries. The two terms are often used synonymously although there lies certain differences, soil quality is related to soil function, whereas soil health presents the soil as a finite non-renewable and dynamic living resource. This brief review will spread light upon the various developments of soil health approaches as well as the content of soil health and soil quality information and its application to reduce negative impacts on agricultural productivity and long term sustainability.

Keywords: Soil Functions, Soil Quality Indices and Soil Organic Carbon

\section{Introduction}

Soil is a natural three-dimensional body which is developed by natural forces acting upon natural materials like rocks and minerals having distinct layers or horizons with distinct physical, chemical and biological characteristics different from those of the parent materials. Soil performs various functions: providing physical support to plants, supplying basic necessities for photosynthesis, providing habitat to diverse variety of soil micro flora and fauna, decomposition of organic and inorganic substances and resisting soil erosion. The production function of soil was recognised long back, however importance of conservation and enhancement of ecosystem services rendered by soil (e.g., carbon sequestration, water purification, biological nitrogen fixation and biodiversity conservation, etc.) has been realized only in recent past with an increasing concern for maintaining and improving soil quality and soil health. This perspective of optimizing multiple functions makes soil health and soil quality an integral part of sustainable agro-ecosystem development.

\section{Soil Health}

It is a condition of soil to function to its full potential to sustain the physiochemical and biological processes as well as promote environment equality and prosperity of plant and animal health.

\section{Soil quality}

The capacity of a soil to function, within natural or managed ecosystem boundaries, to sustain plant and animal productivity, maintain or enhance water and air quality, and support human health and habitation.

\section{Indices to determine Soil Quality}

Soil quality indices are techniques that effectively combine a wide variety of information for multiple objectives. Selection of soil quality indicators is designed by the goal of ecosystem management. If achieving sustainability is the goal of agroecosystem management, a soil quality index will constitute one component within a nested agroecosystem sustainability hierarchy. once the management goals are identified,

\section{Soil quality indexing involves three steps}

(i) selection of soil properties/indicators constituting the minimum data

(ii) transformation of indicator scores for quantification of all indicators to a common measurement scale and 
(iii) combining the indicator scores into the index.

\section{General indicator of soil quality (GISQ)}

Soil organisms and biotic parameters (e.g., abundance, diversity, food web structure, or community stability) meet most of the desired criteria of soil quality indicators (Doran and Zeiss 2000) ${ }^{[2]}$. Velasquez et al. (2007) ${ }^{[14]}$ developed a general indicator of soil quality (GISQ) based on estimation of around 50 soil properties related to macrofauna, chemical fertility, physical state, organic matter fractions and soil morphology.

\section{The computational procedure involved four steps}

(i) PCA analysis of the variables allowing testing of the significance of their variation among land use types;

(ii) identification of the variables that best differentiate the sites according to the soil quality,

(iii) creation of sub-indicators of soil physical quality, chemical fertility, organic matter, morphology and soil macrofauna, with values ranging from 0.1 to1.0;

(iv) combination of all five sub indicators into a general one.

\section{Vegetation attributes as a surrogate to the soil quality}

Another alternative to reduce the cost, time and energy involved in identifying, sampling and classifying soil organisms is to find out environmental parameters which regulate soil fauna composition, e.g., climate, soil and vegetation characteristics. Gillison et al. (2003) ${ }^{[5]}$ found highly significant positive correlations between species richness of all termites and mean canopy height, woody plant basal area, ratio of plant richness to plant functional types, while there was no significant correlation between individual plant and termite species.

\section{Soil organic carbon and carbon management index}

Soil organic matter serves as a primary indicator of soil quality and health for both scientists and farmers (Komatsuzaki and Ohta 2007) ${ }^{[10]}$. Soil organic matter, the primary source and temporary sink for plant nutrients and soil organic carbon in agro-ecosystems has been considered as the best surrogate for soil health (Dumanski and Pieri 2000) ${ }^{[3]}$. The impacts of land management practices are marked in terms of variation in labile fraction of organic carbon or microbial quotients than in total soil organic carbon. Thus, an index derived from both labile and non-labile carbon fractions is likely to be a more sensitive indicator of land use intensification or land management practices compared with a single measure of soil carbon content.

\section{Enzymes as indicators of organic matter quality and} microbial activity

Qualitative and quantitative analysis of soil enzyme generally provide an insight into the biological capacity of soil. Three enzymes viz., phospho-monoesterase, chitinase and phenol oxidase, as a group reflect relative importance of bacteria and fungi, as well as the nature of organic matter complex (Giai and Boerner 2007) [4]. Phosphomonoesterase (acid phosphatase) activity is often correlated with microbial

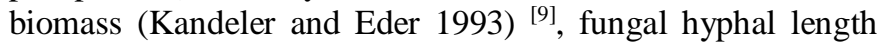
(Haussling and Marschner 1989) ${ }^{[8]}$ and nitrogen mineralization (Decker et al. 1999) ${ }^{[1]}$. Chitinase is a bacterial enzyme which converts chitin, a substance intermediate in its resistance to microbial metabolism produced by fungi and arthropods, into carbohydrates and inorganic nitrogen (Hanzlikova and Jandera 1993) ${ }^{[7]}$. Phenol oxidase is produced primarily by white rot fungi, and is specific for highly recalcitrant organic matter, such as lignin.

\section{Data compression}

Principal Component Analysis (PCA) is a data compression technique designed for data that are in the form of continuous measurements, though it has also been applied in the form of discrete variables to other kind of data such as presence/absence of an element.

Principal Components (PCs) for a data set are defined as linear combinations of the variables that account for variance within the set by describing vectors of closest fit to the $n$ observations in p-dimensional feature space, subject to being orthogonal to one another. The PCA output gives as many PCs as the input variables but it is assumed that PCs receiving high eigenvalues (setting a threshold, e.g., eigenvalues $>1$ ) or those explaining variation in the data exceeding a limit (e.g., $>5 \%$ of the variability) are 'important' and not the others (Wander and Bollero 1999) ${ }^{[15]}$.

\section{Data transformation}

The indicators in question can be transformed following a linear or a non-linear scoring rule. The values of different variables can be transformed to a common range, between 0.1 to 1.0 with homothetic transformation (Velasquez et al. 2007) [14]:

$$
\mathrm{y}=0.1+(\mathrm{x}-\mathrm{b}) /(\mathrm{a}-\mathrm{b}) * 0.9
$$

where,

$\mathrm{y}=$ value of the variable after transformation,

$\mathrm{x}=$ the variable to transform,

$\mathrm{a}=$ the maximum value of the variable,

$\mathrm{b}=$ the minimum value of the variable

Non-linear scoring functions are constructed based on literature review and consensus of the collaborating researchers. Masto et al. (2007) [11] used the following equation for deriving non-linear scores:

$$
\text { -b }(x-a) \text { Non-linear score }(y)=1 / 1+e
$$

where,

$\mathrm{x}=$ soil property value, $\mathrm{a}=$ the baseline or value of the soil property (the scoring function equals 0.5 and equals the midpoint between the upper threshold value and the lower threshold value), and $b=$ slope

\section{Data integration}

There are basically two ways of data integration to derive one soil quality index - by summation of the scores from multidimensional scaling (MDS) indicators and by summation of MDS variables after weighting them by considering the \% variation explained by a PC, standardized to unity, as the weight for variable(s) chosen under a given PC.

\section{Soil fertility and farm level environmental indicators}

Land quality indicators represent generic directives for the functional role of land, indicating condition and capacity of land, including its soil, weather and biolo-gical properties, for purposes of production, conser-vation and environmental management (Parisi et al. 2005) ${ }^{[12]}$. Dumanski and Pieri (2000) ${ }^{[3]}$ have listed four key characteristics of land quality indicators: (i) measurable in space, i.e., over the landscape and in all countries (ii) reflect change over recognizable time 
periods (5-10 years) (iii) showing relationships with independent variables (iv) quantifiable and usually dimensionless. Further, practical utility of an indicator derives from cost effectiveness and precision of its measurement and availability of an interpretative framework to translate it in terms of identifying sustainable management practices (Sparling et al. 2004) ${ }^{[13]}$. Classical soil fertility rating is a function of the crop response to added nutrients and fertilizers recommendations are primarily based on expected financial returns from the crop from applied nutrients rather than an integrated consideration of the costs and benefits of the outcomes of fertilizer addition, e.g., of environmental cost associated with leaching and volatilization of added fertilizers Green accounts or input output accounts are based on a set of indicators to express the degree of environmental impact from a farm based on the use external inputs in relation to the production and/or use of specific management practices (Goodlass et al. 2001) ${ }^{[6]}$. The growing interest in farm level environmental indicators seem to have been derived from a hypothesis, such that environmental improvement of farms supplement mandatory regulation and that farmers will increase their awareness of possible environmental improvements.

\section{Conclusion}

Global acceptance and applications for methodologies of assessment of soil quality and/or health are still in preliminary stage. Further, the existing knowledge provides a better understanding of the current capacity of a soil to function than of making predictions about capacity of the soil to continue to function under a range of stresses and disturbances. Analysis of physical, chemical and biological characteristics of soil is required to evaluate sustainability and guide soil and crop management practices, yet most studies in developing countries is limited to physical and chemical attributes of soil only.

\section{References}

1. Decker KLM, Boener REJ, Morris SJ. Scaledependent patterns of soil enzyme activity in a forested landscape. Canadian Journal of Forest Research. 1999; 29:232-241.

2. Doran JW, Zeiss MR. Soil health and sustainability; managing the biotic component of soil quality. Applied Soil Ecology. 2000; 15:2-11.

3. Dumanski J, Pieri C. Land quality indicators: Research plan. Agriculture, Ecosystems and Environment. 2000; 81:93-102.

4. Giai C, Boerner REJ. Effects of ecological restoration on microbial activity, microbial functional diversity, and soil organic matter in mixed-oak forests of southern Ohio, USA. Applied Soil Ecology. 2007; 35:281-290.

5. Gillison AN, Jones DT, Susilo F, Bignell DE. Vegetation indicates diversity of soil macroinvertebrates: a case study with termites along a land-use intensification gradient. Organisms, Diversity and Evolution. 2003; 3:111-126.

6. Goodlass G, Halberg N, Versschuur G, Hanegraff MNC. Study on Input/Output Accounting Systems on EU Agricutlural Holdings, 2001. http://europa.eu.int/environment/agriculture/pdf/input.out put.pdf. (Accessed on 23 February rd 2012).

7. Hanzlikova A, Jandera A. Chitinase and changes of microbial community in soil. Folia Microbiologica. 1993; $38: 159160$.
8. Haussling M, Marschner H. Organic and inorganic soil phosphates and acid phosphatase activity in the rhizosphere of 80-year-old Norway spruce (Piceaabies (L.) Karst.) trees. Biology and Fertility of Soils. 1989; 8:128-133.

9. Kandeler E, Eder G. Effect of cattle slurry in grassland on microbial biomass and on activities of various enzymes. Biology and Fertility of Soils. 1993; 16:249254.

10. Komatsuzaki M, Ohta H. Soil management practices for sustainable agro-ecosystems. Sustainability Science. 2007; 2:103120.

11. Masto RE, Chhonkar PK, Singh D, Patra AK. Soil quality response to long-term nutrient and crop management on a semi-arid inceptisol. Agriculture, Ecosystems and Environment. 2007; 118:130-142.

12. Parisi V, Menta C, Gardi C, Jacomini C, Mozzanica E. Microarthropod communities as a tool to assess soil quality and biodiversity: a new approach in Italy. Agriculture, Ecosystems and Environment. 2005; 105:323-333.

13. Sparling GP, Schipper LA, Bettjeman W, Hill R. Soil quality monitoring in New Zealand: practical lessons from a 6year trial. Agriculture, Ecosystems and Environment. 2004; 104:523534.

14. Velasquez E, Lavelle P, Andrade M. GISQ, a multifunctional indicator of soil quality. Soil Biology and Biochemistry. 2007; 39:3066-3080.

15. Wander MM, Bollero GA. Soil quality assessment of tillage impacts in Illinois. Soil Science Society of America Journal. 1999; 63:961-971. 